DOI: https://doi.org/10.47405/mjssh.v6i11.1165

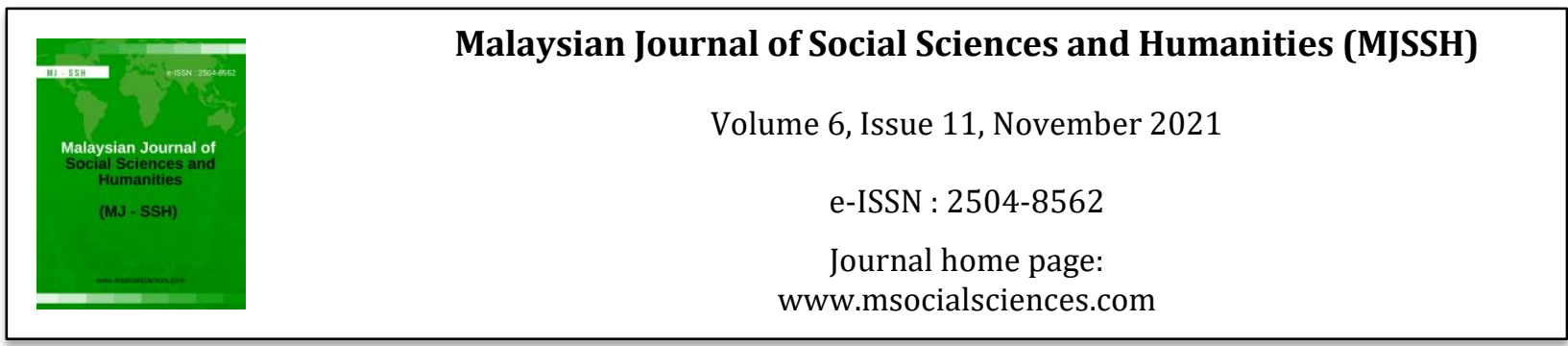

\title{
Perkaitan Rutin Aktiviti dan Jenayah Serangan Seksual Ke Atas Wanita
}

\author{
Nurul Asyikin Zainal Abidin'1, Mohamad Fauzi Sukimi' ${ }^{1}$, Muhamad Fuad Abdul Karim² \\ 1Universiti Kebangsaan Malaysia (UKM), Malaysia \\ 2Universiti Teknologi Mara, Malaysia
}

Correspondence: Nurul Asyikin Zainal Abidin (nasyikinzainall@gmail.com)

\begin{abstract}
Abstrak
Viktimisasi membincangkan perlakuan jenayah dari sudut pandang dan fokus terhadap mangsa jenayah. Kajian literatur terhadap Teori Aktiviti Rutin digunakan dalam memahami jenayah serangan seksual ke atas wanita sebagai mangsa. Teori Aktiviti Rutin menyatakan seseorang menjadi mangsa disebabkan keterlibatan tiga pihak iaitu pemangsa bermotivasi, mangsa yang menarik dan ketiadaan penjaga yang berkebolehan; dan individu yang menghabiskan banyak masa di luar rumah mempunyai risiko yang lebih tinggi untuk menjadi mangsa. Jadi kajian bertujuan untuk melihat apakah lokasi kejadian mempengaruhi serangan seksual yang terjadi. Kajian ini menggunakan reka bentuk kajian kualitatif dengan pendekatan kajian kes dan aplikasi teknik temu bual mendalam terhadap 11 orang informan bagi melihat faktor yang mencetuskan serangan seksual. Hasil kajian mendapati bahawa mangsa tidak sendirinya mencetuskan serangan seksual ke atas diri mereka sebaliknya tidak berdaya di atas faktor tinggal serumah bersama pemangsa, berseorangan dan kegagalan penjaga menjalankan tanggungjawab dengan baik. Kesimpulannya, viktimisasi terhadap mangsa serangan seksual tidak dicetuskan oleh mangsa sendiri tetapi mangsa merupakan individu yang tidak berdaya dan tidak bernasib baik.
\end{abstract}

Kata kunci: viktimisasi, teori aktiviti rutin, serangan seksual

\section{The Association of Routine Activities and The Crime of Sexual Assault on Women}

\begin{abstract}
Victimization discusses criminal behavior from the point of view and focus on victims of crime. A review of the literature on Routine Activity Theory is used in understanding the crime of sexual assault on women as victims. Routine Activity Theory states that a person becomes a victim due to the involvement of three parties namely a motivated predator, an attractive victim and the absence of a competent guardian; and individuals who spend a lot of time outdoors have a higher risk of becoming victims. So, the study aimed to see if the location of the incident influenced the sexual assault that took place. This study uses a qualitative study design with a case study approach and the application of in depth interview techniques to 11 informants to see the factors that trigger sexual assault. The results of the study found that the victims did not purposely trigger sexual attacks on themselves but were helpless due to the factors of living at home with the predator, alone and the failure of guardian to carry out their responsibilities properly. In conclusion, the victimization of a victim of sexual assault is not triggered by the victim but the victim is a helpless and unfortunate individual.
\end{abstract}

Keywords: victimization, routine activity theory, sexual assault 


\section{Pengenalan}

Serangan seksual didefinisikan sebagai tindakan di mana seseorang sengaja secara seksual menyentuh orang lain tanpa persetujuan orang itu, atau memaksa atau memaksa seseorang untuk melakukan perbuatan seksual terhadap kehendak mereka (Cameron, 2011). Wanita menjadi mangsa serangan seksual pada kadar yang lebih tinggi berbanding lelaki pada kadar 1.8 setiap 1000 orang manakala lelaki hanya 0.3 setiap 1000 orang (BJS, 2003). Isu serangan seksual bukanlah perkara baru dalam masyarakat kita. Ramai wanita sudah menjadi mangsa namun memutuskan hal ini sebagai sesuatu yang peribadi dan tidak perlu untuk dikongsikan bersama. Jadi mereka memilih untuk tidak melaporkan kes yang berlaku dan hal ini telah menyumbang kepada peratusan sebanyak 80 peratus wanita tidak melapor kepada pihak berkuasa meskipun disediakan talian aduan (Berita Harian, 2018). Menurut salah satu kajian di Barat menyatakan statistik sekurang-kurangnya 15\% hingga 25\% wanita kolej adalah mangsa seksual (Fisher, Cullen, \& Turner, 2000; Krebs et al., 2007).

Serangan seksual paling kerap berlaku bukan di lorong gelap, tetapi di dalam bilik asrama atau apartment di mana wanita itu berada dalam konteks hubungan sosial (Noga \& Terri, 2013). Menurut perangkaan United Nations Entity for Gender Equality and the Empowerment of Women (UN Women) United Nation, mendapati seorang daripada tiga wanita biasanya akan mempunyai pengalaman serangan seksual sekurang-kurangnya sekali seumur hidup (Berita Harian, 2018). Di Malaysia, Berita Harian melaporkan terdapat sebanyak 230 kes serangan seksual dilaporkan berbanding sebanyak 190 pada tahun 2014. Jumlah peningkatan kes direkodkan ialah 40, tetapi ia disifatkan serius oleh Kementerian Pembangunan Wanita, Keluarga dan Masyarakat (KPWKM). Hal ini demikian kerana mengambil kira faktor kes gangguan seksual amat sukar didedahkan oleh mangsa, masih ramai lagi mangsa menganggap ianya sesuatu yang memalukan apabila didedahkan atau tidak sedar mereka telah menjadi mangsa gangguan seksual (Berita Harian, 2015). Kelemahan undang-undang dan peraturan sedia ada mencetuskan peningkatan kes sekaligus mendesak penggubalan Akta Gangguan Seksual. Banyak kes semakin mendapat perhatian sama ada di media cetak mahupun media elektronik. Pendedahan dan fokus dinyatakan secara dasar sahaja seperti bila kejadian berlaku, lokasi, bagaimana dan beberapa.

\section{Sorotan Literatur}

\section{Teori Aktiviti Rutin}

Rajah 1 menunjukkan segi tiga jenayah Teori Aktiviti Rutin memperkenalkan garis panduan atau petunjuk penting dalam analisis jenayah. Segi tiga kejahatan menganalisis ketiga-tiga elemen jenayah iaitu mangsa yang berisiko, pemangsa yang bermotivasi dan penjaga yang berkebolehan berserta kemungkinan jenayah terjadi. Teori Aktiviti Rutin menerangkan dari bidang viktimisasi di mana ketiga-tiga elemen perlu digabungkan atau wujud serentak untuk memungkinkan viktimisasi terjadi. Juga menyatakan jenayah dan viktimisasi tidak berakar sebagai satu patalogi sosial kerana ianya terjadi melalui rutin-rutin harian seperti meninggalkan rumah untuk membeli barang dan pergi ke tempat kerja misalnya. Jika individu melalui kawasan persekitaran yang berisiko tinggi untuk berlakunya jenayah maka individu tersebut sudah berisiko untuk menjadi mangsa. Risiko akan wujud jika seseorang individu itu berada dan terlibat dalam persekitaran yang berisiko tinggi maka kemungkinan untuk menjadi mangsa juga turut bertambah.

Teori Aktiviti Rutin merupakan satu teori yang sering digunakan untuk menjelaskan mengapa suatu jenayah itu berlaku (Ugur \& Murat, 2006). Cohen dan Felson (1979) percaya bahawa jenayah berlaku melibatkan tiga elemen yang merupakan sasaran yang sesuai, ketiadaan penjaga yang berkebolehan, dan pemangsa yang bermotivasi. Ketiga-tiga unsur ini harus wujud untuk menjadikan teori ini digunakan dalam sesuatu kes atau kajian. Seterusnya, Teori Aktiviti Rutin menyatakan seseorang bertanggungjawab dalam menentukan tingkah laku dan rutin harian yang dilakukan setiap hari sama 
ada berisiko menjadi mangsa jenayah mahupun tidak. Pernyataan ini jelas meletakkan kesalahan dan tanggungjawab kepada seseorang individu terhadap jenayah yang berkemungkinan terjadi ke atas mereka, jika mereka melakukan aktiviti yang berisiko.

\section{Rajah 1: Segitiga Rajah Teori Aktiviti Rutin}

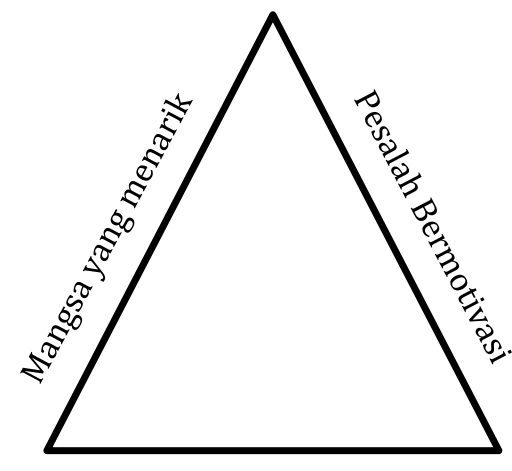

Penjaga Tidak Berkebolehan

Sumber: Cohen dan Felson (1979)

\section{Viktimisasi}

Victimization merupakan satu tindakan atau proses bagaimana seseorang menjadi mangsa (Viano, 1976). Kebimbangan terhadap viktimisasi ke atas wanita telah meningkat. Viktimologi merupakan satu bidang yang menyatakan setiap individu berkebarangkalian ditimpa masalah disebabkan faktor lokasi dan masa yang salah. Namun, persoalan yang timbul adalah bagaimana seseorang itu ditimpa masalah sama ada melalui sifat seseorang, faktor sosial, atau budaya yang memaksa seseorang untuk mengambil risiko dan membahayakan nyawanya. Teori Aktiviti Rutin akan membincangkan dan menganalisis apakah yang dimaksudkan dengan mangsa yang menarik atau mangsa ideal dengan melihat lokasi kejadian bagi melihat tahap pendedahan mangsa dengan viktimisasi. Hal ini bertujuan untuk menjawab kepada paradoks serangan seksual bahawa mangsa bertanggungjawab ke atas serangan seksual yang terjadi atas diri mereka. Budaya rogol gaya hidup dan aktiviti seseorang mangsa itu membawa kepada risiko menjadi mangsa gangguan seksual ataupun sebaliknya.

\section{Kritikan Kepada Teori}

Terdapat pelbagai jenis kejadian jenayah yang sering berlaku antaranya adalah penculikan, kecurian, serangan seksual, penderaan seksual, jenayah politik, jenayah kolar putih, jenayah ekonomi, jenayah siber, keganasan rumah tangga dan sebagainya. Teori ini banyak membincangkan viktimolgi dalam sudut pandang jenayah jalanan seperti rompakan dan serangan. Sekiranya dilihat dari sudut pandang lokasi kejadian teori menunjukkan dan menerangkan mengenai jenayah yang berlaku di luar rumah dan jika kita melihat dari sudut pandangan lokasi kejadian teori menunjukkan jenayah berlaku pada malam hari, tempat awam, kawasan risiko tinggi jenayah berlaku. Teori ini tidak mengemukakan penyelesaian yang ideal untuk situasi seperti itu yang telah dijelaskan walaupun masyarakat dan jenayah berbeza antara satu sama lain. Individu, persekitaran situasi dan jenis jenayah tidak sama di setiap lokasi, begitu juga peluang yang wujud.

Seterusnya, Teori Aktiviti Rutin menyatakan bahawa rumah merupakan tempat yang selamat dan sekali gus menyatakan meninggalkan rumah dianggap sebagai satu aktiviti yang berisiko (Pratt \& Turanovic, 2016). Menurut definisi aktiviti rutin ini, individu yang menghabiskan lebih banyak masa di luar rumah harus mempunyai risiko viktimisasi yang lebih tinggi kerana kesesuaian mereka yang lebih besar sebagai sasaran. Sebagai contoh, jenayah rompakan masih boleh terjadi walaupun mangsa berada rumah pencuri masih boleh melakukan jenayah jika mempunyai peluang. Peluang juga tidak 
semestinya terbuka dengan ketiadaan mangsa tetapi sebaliknya apabila ada dengan kewujudan pemangsa yang mempunyai niat. Dalam kajian ini, mangsa serangan seksual juga tidak semestinya harus meninggalkan rumah untuk memungkinkan kejadian serangan seksual terjadi ke atas dirinya kerana selagi ada pemangsa yang bermotivasi, seperti orang yang tinggal di dalam rumah itu sendiri atau orang luar yang berpeluang untuk menyerang mangsa secara seksual di rumah. Pemangsa boleh terdiri dalam kalangan orang yang tinggal di dalam rumah.

Wikstrom (2009) menyatakan idea utama adalah aktiviti rutin dalam masyarakat mempengaruhi apa sahaja jenis situasi yang muncul, dan perubahan dalam aktiviti rutin masyarakat menyebabkan perubahan dalam jenis situasi yang dihadapi seseorang individu. Pengkaji ingin melihat sama ada rutin aktiviti mangsa menyebabkan seseorang menjadi mangsa, faktor tambahan yang menyumbang atau sememangnya rutin harian mangsa tidak langsung menyebabkan individu menjadi mangsa bermakna hanya pemangsa yang bermotivasi dan ketiadaan penjaga yang berkebolehan sahaja menyebabkan seseorang itu dijadikan mangsa.

Teori Aktiviti Rutin menerangkan dari sudut viktimisasi di mana ketiga-tiga elemen perlu digabungkan atau wujud serentak untuk memungkinkan viktimisasi terjadi. Jika individu melalui kawasan persekitaran yang berisiko tinggi untuk berlakunya jenayah maka individu tersebut sudah berisiko untuk menjadi mangsa. Risiko akan wujud jika seseorang individu itu berada dan terlibat dalam persekitaran yang berisiko tinggi maka kemungkinan untuk menjadi mangsa juga turut bertambah. Seterusnya, menurut Hindelag (1978) Teori Aktiviti Rutin mewakili perubahan gaya hidup dan modenisasi yang menyebabkan seseorang itu dijadikan mangsa. Sebagai contoh, modenisasi pada hari ini membuatkan seseorang wanita itu bekerja dan pulang sehingga lewat malam hingga meningkatkan risiko dirinya menjadi mangsa.

Rajah 2: Indikator Kajian

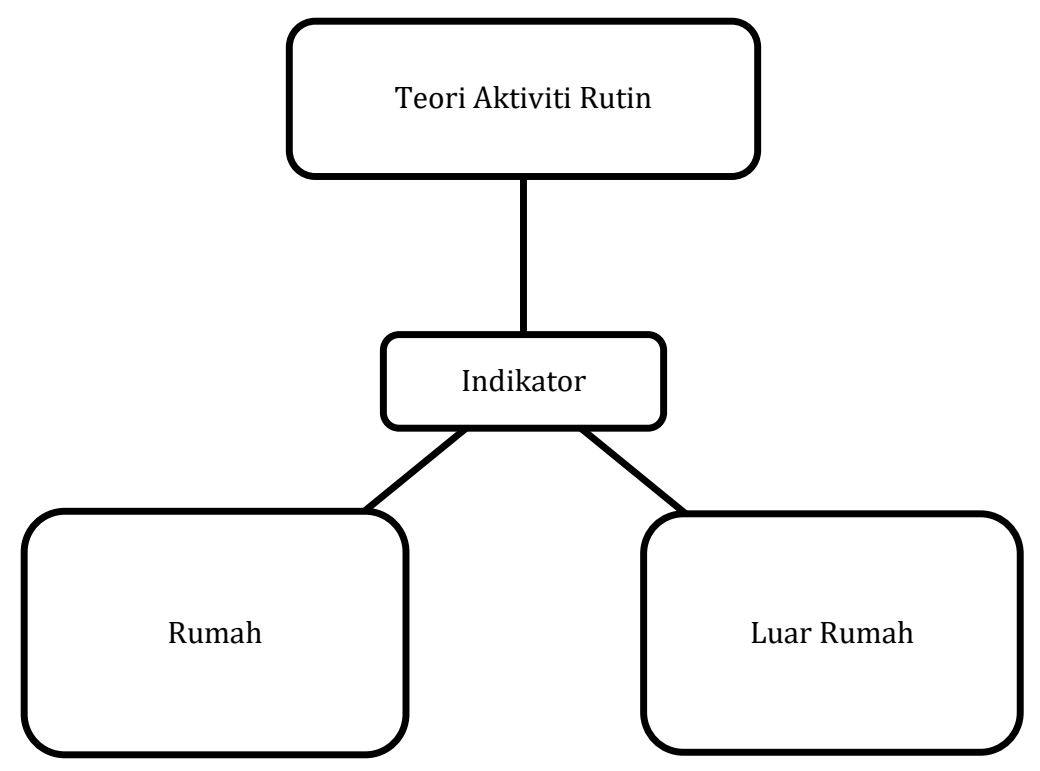

Lokasi serangan seksual dijadikan sebagai indikator di dalam kajian ini bagi melihat faktor yang mencetuskan serangan seksual ke atas diri mangsa. Adakah jenayah sering berlaku di rumah atau luar rumah atau kawasan awam yang lain. Faktor-faktor serangan seksual terjadi penting bagi menjawab kepada stigma mangsa bertanggungjawab dia atas rutin aktiviti mereka yang berisiko hingga menyebabkan jenayah terjadi. Jenayah yang berlaku di luar rumah adalah bagi melihat adakah mangsa meninggalkan rumah terlibat dengan gaya hidup dan lokasi yang berisiko. 


\section{Metod Kajian}

Kajian ini mengaplikasikan pendekatan kualitatif ke atas 11 orang informan yang dipilih melalui teknik pensampelan bertujuan. Kaedah temu bual mendalam berpandukan soalan separa struktur dan pemerhatian tidak ikut serta digunakan. Paradigma penyelidikan ontologi idealis dan epistemologi konstruktivis sosial digunakan bagi menilai pemahaman mengenai isu serangan seksual. Tinjauan kritis terhadap teori akan dikemukakan seterusnya diaplikasikan dalam memahami isu kajian serangan seksual ke atas wanita.

\section{Hasil Kajian}

\section{Lokasi}

Mengikut Teori Rutin Aktiviti kemungkinan jenayah berlaku lebih tinggi apabila mangsa berada seorang diri di lokasi yang berisiko tinggi bagi kegiatan jenayah berlaku. Lorong-lorong gelap dan keluar pada waktu malam antara faktor meningkatnya risiko jenayah ke atas diri sendiri. Ada juga kajian dilakukan yang bertujuan untuk mengaitkan korban dengan serangkaian tingkah laku rutin seharian yang berlaku di luar rumah, seperti pergi bekerja dan membeli-belah (lihat, misalnya, Kennedy \& Forde, 1990; Miethe, Stafford, \& Long, 1987). Kejadian boleh berlaku di mana-mana sahaja. Jika rumah dikatakan tempat yang selamat jenayah maka, tidak akan berlaku di rumah atau setidaknya jenayah di rumah pasti berada di statistik yang terendah. Hasil daripada analisis kajian kes. (Lihat Jadual 1.0).

Jadual 1: Lokasi Kejadian

\begin{tabular}{|c|c|c|c|}
\hline Informan & Kategorisasi & $\begin{array}{l}\text { Pengalaman } \\
\text { sewaktu umur }\end{array}$ & $\begin{array}{l}\text { Hubungan dengan } \\
\text { pemangsa }\end{array}$ \\
\hline Farah & Di dalam kereta & 26 tahun & $\begin{array}{l}\text { Rakan internet yang } \\
\text { baru dikenali }\end{array}$ \\
\hline Squeeze & Di rumah & 11 tahun & $\begin{array}{l}\text { Orang asing (Tukang } \\
\text { Urut) yang tidak } \\
\text { dikenali }\end{array}$ \\
\hline Maia & Di dalam kenderaan awam LRT & 18 tahun & Orang Asing \\
\hline Ven & Di rumah & 9 tahun & Abang kandung \\
\hline Kina & Di rumah & 29 tahun & Orang Asing \\
\hline Reen & Di rumah & 4 tahun & Bapa saudara \\
\hline Tera & Di pejabat & 23 tahun & $\begin{array}{l}\text { Pegawai atasan dalam } \\
\text { organisasi }\end{array}$ \\
\hline Tammy & $\begin{array}{l}\text { Di rumah \& kereta \& pusat membeli } \\
\text { belah \& gereja }\end{array}$ & $\begin{array}{l}7 \text { tahun } \\
14 \text { tahun }\end{array}$ & $\begin{array}{l}\text { - Bapa saudara } \\
\text { - Bekas teman lelaki }\end{array}$ \\
\hline Alia & $\begin{array}{l}\text { Di kawasan perumahanan \& rumah \& } \\
\text { kereta }\end{array}$ & $\begin{array}{l}20 \text { tahun } \\
7 \text { tahun } \& 24 \text { tahun }\end{array}$ & $\begin{array}{l}\text { - Orang asing } \\
\text { - Lelaki yang baru } \\
\text { dikenali } \\
\text { - Bapa kandung }\end{array}$ \\
\hline Daisy & $\begin{array}{l}\text { Di rumah \& bilik air \& pusat membeli } \\
\text { belah \& taman rekreasi }\end{array}$ & 10-19 tahun & $\begin{array}{l}\text { - Bapa Tiri } \\
\text { - sahabat }\end{array}$ \\
\hline Yaya & Di rumah & 8-9 tahun & - Abang kandung \\
\hline
\end{tabular}


Kajian kes menunjukkan 8 daripada 11 informan yang telah ditemu bual mempunyai pengalaman serangan seksual di rumah mereka sendiri. Pernyataan ini dapat membuktikan bahawa rumah bukanlah tempat yang selamat bagi jenayah serangan seksual. Mangsa juga berada dalam lingkungan bawah umur dan tidak berdaya untuk mengelakkan diri daripada menjadi mangsa. Rumah sering ditinggalkan tanpa kawalan ketika ketiadaan ibu bapa (Argun, 2016). Jadi kritikan terhadap teori yang menyatakan rumah merupakan tempat yang selamat boleh dibuktikan bahawa pernyataan itu tidak benar dan disokong dengan data kajian kes. Selain Farah, Tera dan Maia, informan lain masing-masing mempunyai pengalaman di rumah. Penafian rumah merupakan tempat yang selamat adalah tidak dapat disangkal lagi. Malah penjaga yang seharusnya melindungi masa gagal menjalankan tanggungjawab dengan baik.

\section{Penjaga yang Tidak Berkebolehan}

Kejadian serangan seksual yang berlaku di rumah melibatkan Daisy, Alia, Squeeze, Yaya, Ven, Tammy, Reen dan Kina. "He do that when my mom is around, he do that when there's people around, our relatives, his friends. Whenever he can. For 9 years". Pernyataan Squeeze menunjukkan beliau terdedah dengan pemangsa dan menjadi tidak berdaya untuk mengelakkan diri daripada pemangsa. Jika diambil kira Daisy yang tinggal bersama ibu kandungnya, ibu kandungnya secara tidak langsung merupakan penjaga yang sah dan harus melindungi mangsa. Ibu kandung mangsa sebagai penjaga gagal melindungi mangsa walaupun setelah mengetahui mangsa menjadi mangsa serangan seksual oleh suami (bapa tiri). Ketidakberdayaan dan keadaan mangsa yang tinggal dengan pemangsa menyulitkan keadaan. Kegagalan penjaga melindungi mangsa menyebabkan kejadian berlaku selama 8 tahun setiap kali pemangsa itu mempunyai peluang.

Alia membuat pernyataan seperti berikut:

"Bila adik-adik saya datang saya nangis lagi dan balik tu saya bagitau mak saya details pakaian dia baju warna apa tapi my parents tak buat report polis pun. Saya bagitau details sebab lelaki tu bodoh dan bagitahu dia duduk mana, dia cakap lepas saya nangis tu dia cakap 'nanti cari abang ye, abang duduk blok C 2-02 something."

Beliau menjadi mangsa ketika berumur 7 tahun oleh seorang remaja yang beliau pasti tinggal di kawasan perumahan yang sama. Setelah memaklumkan hal itu pada ibunya, perkara itu tidak dihiraukan sehingga mewujudkan trauma dalam diri mangsa. Tindakan ibu sebagai penjaga yang tidak mempercayai anaknya mewujudkan keraguan kepada mangsa untuk mencari pertolongan.

Squeeze menyatakan:

'My mother tried to fix I by calling 'orang berubat' to our house. He was an old man, probably in early 70 s"

Pernyataan dapat dilihat di mana ibu Squeeze yang cuai dalam pembuatan keputusan telah menjadi mangsa serangan seksual sekaligus menyebabkan kedua-dua anak perempuannya menjadi mangsa tukang urut yang mengambil kesempatan. Melihat kepada pernyataan mangsa apabila ibunya bertanya adakah Squeeze mengalami perkara yang sama bermakna ibunya pada ketika itu tidak memantau sewaktu mangsa diurut. Jika diambil kira umur mangsa yang pada ketika itu hanya 11 tahun, ibunya tidak seharusnya memberi sepenuh kepercayaan kepada orang luar yang baru sahaja dikenali. Dalam hal ini, kewujudan Squeeze sebagai kanak-kanak yang berpotensi atau dilihat mudah dimanipulasikan tambahan dengan ketiadaan lelaki di rumah, ketidakberdayaan ibu mangsa sebagai penjaga dan pemangsa iaitu tukang urut yang bermotivasi melengkapkan segi tiga jenayah yang dibina oleh Cohen dan Felson (2014).

Pernyataan daripada Yaya: "I was sexually assaulted by my own brother in my own house. He would kiss me, make me hold his private parts and he would touch mine too I was too little so i didnt know what was happening. I know it was wrong but telling it to anybody would make a huge mess and $i$ would like to avoid that. By the 
way the whole family usually sleep together so basically every morning my mom dah bangun buat kerja dia kat rumah and my dad pun dah takde kat bilik so $i$ was left alone w my brother and that was when he did those things to me."

Pernyataan ini menunjukkan kejadian berlaku semasa Yaya berumur 9 tahun oleh abang kandung mangsa yang pada ketika hanya dua tahun lebih tua daripadanya. Hal ini menunjukkan jelas bahawa ibu bapa Yaya tidak memantau dan menyediakan ajaran yang baik kepada anak-anak mereka. Mereka tidak memisahkan tempat tidur anak lelaki dan perempuan menyebabkan timbul hal-hal yang tidak diingini seperti itu. Kejadian ini berkemungkinan dapat dielakkan jika ibu bapa memberi pendidikan yang betul serta memantau keadaan anak-anak mereka dari masa ke semasa.

Pernyataan daripada Ven yang menjadi mangsa serangan seksual daripada abang kandung dan sepupunya:

"He asked me to go into his room in daytime. I don't think my parents were at home, and I think my sisters were downstairs. Was told to go into his room. Told me to not tell anyone, and asked me to lie down on his bed. He gave me a rm2 note, and pulled down my pants to stare at my genita ." dan "Another one was at my grandmother's house. I can't remember when, but I think it was still when I was in primary school. You know all family gathering and sleep in living room thing? While I was sleeping, $i$ was awoken by something that rubbed my genital. I opened my eyes to peep, it was my cousin."

Seterusnya berlaku kepada Tammy juga ketika berada di rumah dan tidur di ruang tamu bersama ahli keluarganya yang lain:

"I was probably 7 years old. Was sleeping in the living room with my cousins. Maybe about 2 am in the morning, an uncle came home drunk. Slept on my mom's side of the bed and he slowly put his hand in my pants. I terbangun lah sebab rasa macam ada benda di bawah tu. He wanted to finger me but tidak jadi coz ada bunyi kucing kasi jatuh barang outside."

Pernyataan daripada Reen: "During Hari Raya visit to one of the relatives house, one of my uncles pulled me aside to the balcony and dark corner and started fingering me."

Mangsa pada ketika itu masih di usia remaja ketakutan dan tidak berdaya untuk membuat apa-apa dengan situasi seperti itu. Kedua-dua serangan terhadap mangsa berlaku di rumah dengan keberadaan penjaga namun pemangsa yang bermotivasi tetap melakukan serangan seksual terhadap mangsa. Mangsa masing-masing menjadi mangsa serangan seksual semasa berada di rumah dengan keberadaan penjaga namun tidak berkebolehan melindungi mereka. Tambahan lagi, wujudnya satu paten dalam kajian kes ini iaitu kanak-kanak perempuan dalam lingkungan usia empat hingga 19 tahun telah menjadi mangsa. Golongan muda berada dalam kategori pertama yang paling tidak berdaya (Mieths, 1985). Ketidakberdayaan mangsa telah menyebabkan diri mereka dilihat sebagai target yang mudah agar tidak sukar didekati pemangsa yang bermotivasi (NSW Attorney Offender, 2011).

Secara kesimpulannya dapat dirumuskan daripada kesemua kes yang dinyatakan adalah kegagalan penjaga melaksanakan tugas mereka dengan baik sehingga menyebabkan serangan seksual berlaku kepada mangsa dan lebih kritikal terus berlaku. Mengambil kira situasi mangsa, penjaga dan pemangsa yang berada di dalam satu rumah yang sama menyukarkan keadaan bagi mangsa bertindak. Jika penjaga sebagai orang yang paling dipercayai dan hampir tidak memberi kepercayaan kepada mangsa serangan seksual yang berlaku di rumah atau melibatkan ahli keluarga tidak akan dapat diselesaikan. Dalam hal ini, mangsa telah bertindak dengan cubaan mencari bantuan seperti Daisy dan Alia yang mencuba memberitahu ibu mereka namun tidak dihiraukan. Kedua, niat dan keinginan pemangsa tidak boleh dinafikan dalam mana-mana serangan seksual. Rasionalnya tidak ada satu pun individu yang cuba atau mempunyai keinginan melibatkan diri mereka dari menjadi mangsa. 


\title{
Gaya Hidup Mangsa
}

Seterusnya, hasil kajian membincangkan serangan seksual yang berlaku berdasarkan pilihan gaya hidup mangsa. Dalam hal ini, mangsa yang berkemungkinan juga mengikut rutin aktiviti yang memisahkan diri mereka daripada penjaga yang berkebolehan di tempat yang mempunyai pengurusan yang lemah telah menyebabkan diri mereka menjadi mangsa. Beliau menjadi mangsa kerana sedang berseorangan di rumah dan tidak bersedia dengan serangan seksual yang mungkin terjadi. Mangsa juga menyatakan dia tinggal berseorangan di apartmen yang kalis bunyi telah menyebabkan dirinya dilihat sebagai target yang mudah bagi pemangsa. Peluang yang wujud disitu telah menjadi pencetus kepada pemangsa yang bermotivasi itu melakukan serangan.

Pernyataan Kina adalah seperti berikut:

"I was moving in to a new condo and had thought of using one of those pesticide companies to come over first and spray the unit, a Malay guy came, a few years younger than me, I was alone since I usually prefer to go about doing my own stuff. The typical independent woman kinda way. We talked and After that he grabbed me from behind and tried to kiss my lips when I was surprised and turned around aushed him away but at that point I was too shocked to do anything but stare trying to remember every single advice I'd ever received if I was ever in a situation like that but I was too scared, I know I was the only person on the floor and my house was soundproof, so I tried to be calm and told him to get out of the house, he kept on coming closer and repeating how lonely he was and he needed a womens touch and me, still scared. still trying to be calm thinking if I was aggressive it might turn him on and make him be aggressive as well he attempted to hug me and kiss me again managed to hug me and grope me before I pushed him off and pushed him towards the door."

"Around peak hour, so the train was very packed but not packed enough that my body would be touching a complete stranger if that makes sense. I got in the train and felt someone graze by my back but i thought they were just a person trying to go into the train and had to maneuver so i didn't think much of it."

Pernyataan daripada Maia pula yang menjadi mangsa ketika menggunakan perkhidmatan pengangkutan awam LRT berseorangan namun tidak sunyi juga telah menyebabkan dirinya menjadi mangsa, sedangkan pengangkutan awam tidak dilihat sebagi tempat yang tinggi risiko jenayah berlaku.

\begin{abstract}
"After that we headed to a bar to have a drink. He knew the bartender so I think it was a bar he frequents. We chatted and talked. We bar hopped to a few more bars, and I had few more drinks. I realised I started to get tipsy, and then I couldn't walk properly after the fourth drink. . I was drunk at this point, but I could still process what was happening. He started touching me arm, to my chest. I asked him to stop, and I told him he shouldn't take advantage of me. I remember at some point he stopped the car somewhere to smoke, and I tried to get out of the car. I was dizzy so my reaction wasn 't very strong."
\end{abstract}

Seterusnya pernyatan di atas menunjukkan gaya hidup yang dikatakan berisiko menurut Kennedy \& Forde (1990), yang menyatakan pergi ke bar merupakan berisiko bagi jenayah vikmisasi berlaku. Pilihan gaya hidup oleh Farah telah mencetuskan pemangsa yang bermotivasi kerana mangsa telah minum minuman beralkohol dan kurang daya diri sehingga pemangsa mudah mengambil kesempatan ke atas dirinya.

Pernyataan daripada Tera adalah seperti berikut:

"But senior executive ni dia memang suka cuit-cuit. Dia memang purposely shove right at my face. Sebab I was sitting kat kerusi kan. He was standing. So, the level 
of his thing to my face straight. Then, I terus jerit and guard dtg. Guard tu penyelamat actually."

Gaya hidup yang dipilih Tera tidak termasuk dalam kategori aktiviti berisiko. Mangsa hanya menjadi mangsa serangan seksual di tempat kerja oleh atasan dan keluar daripada rumah dengan pergi ke tempat adalah sesuatu yang normal dilakukan oleh wanita apda ahri ini. Pemangsa di sini sememangnya mempunyai motif untuk menyerang mangsa secara seksual sebelum pengawal keselamatan datang disebabkan Tera menjerit. Keadaan ini menjadikan pengawal keselamatan yang muncul sebagai penjaga yang berkebolehan dan telah melindungi mangsa dari situasi yang lebih buruk. Hasil kajian daripada 11 orang informan mendapati tujuh dari serangan seksual terjadi di rumah di mana keberadaan penjaga yang tidak berkebolehan dan kukuh. Daripada tujuh daripada mangsa Alia dan Squeeze sahaja yang tidak melibatkan serangan seksual oleh pemangsa yang tidak mempunyai ikatan kekeluargaan. Pernyataan ini menunjukkan mangsa dilihat sebagai target yang menarik kerana tinggal di dalam rumah yang sama dengan pemangsa. Pemangsa yang sememangnya bermotivasi berkemampuan melihat rutin aktiviti mangsa dengan baik. Manakala, bagi Alia dan Daisy juga menunjukkan kegagalan penjaga untuk melindungi mereka dengan tindakan pengabaian oleh ibu mereka. Penjaga kepada Squeeze iaitu ibu mangsa juga menunjukkan kecuaian penjaga telah menyebabkan viktimisasi berlaku. Seterusnya hasil kajian menunjukkan satu budaya dalam masyarakat kita yang tidak memisahkan tempat tidur bersama ahli keluarga menyebabkan individu lebih mudah diserang secara seksual atas faktor-faktor tidak tidur di bilik sendiri, percampuran tempat tidur antara adik beradik dan ahli keluarga serta perkongsian lokasi oleh mangsa dan pemangsa. Ketidakberdayaan mangsa telah memungkinkan serangan berlaku. Analisis menurut Teori Aktiviti Rutin jelas menunjukkan pemangsa di sini melakukan serangan kerana mempunyai niat dan ditambah dengan kelemahan penjaga telah menjadikan mangsa yang tidak berdaya ini terlibat dalam viktimisasi.

\section{Kesimpulan}

Kesimpulannya, kenyataan daripada Teori Aktiviti Rutin yang menyatakan meninggalkan rumah meningkatkan risiko viktimisasi (Cohen \& Felson, 1979) sekaligus menyatakan bahawa rumah merupakan tempat yang selamat adalah tidak dapat dibuktikan dengan analisis kajian kes. Kejadian serangan seksual juga berlaku di dalam rumah dan lebih kritikal kerana seringkali pemangsa tinggal bersama-sama mangsa. Pemangsa memanipulasikan faktor lokasi yang dilihat lebih mudah untuk melakukan serangan iaitu rumah. Seterusnya, faktor mangsa yang berseorangan adalah penyebab yang mencetuskan pemangsa untuk membuat keputusan. Ketiga, berdasarkan analisis kajian kes wanita yang berada di bawah umur lebih banyak dijadikan mangsa serangan seksual kerana dilihat lebih mudah dan tidak berdaya secara fizikal diikuti dengan mangsa hilang kawalan diri disebabkan aktiviti berisiko kerana mabuk. Peluang tidak akan terbina jika wujudnya penjaga yang berkebolehan untuk mengawal situasi ini. Selain itu, peluang wujud atas pilihan peribadi pemangsa mengikut lokasi yang dirasakan mudah untuk melakukan serangan seksual. Pernyataan jenayah tidak berlaku dengan sendirinya tanpa penyebab yang diwujudkan oleh mangsa, iaitu wanita, merupakan satu pernyataan yang tidak berasas. Jika diikutkan situasi di mana jenayah berlaku semasa keberadaan penjaga di mana mangsa dan pemangsa tinggal serumah, adakah wajar diletakkan kesalahan kepada mangsa seperti mengapa mangsa tidak melarikan diri atau membuat laporan polis? Mangsa berada di bawah umur dan ketidakberdayaan melindungi diri mangsa merupakan salah satu faktor yang menunjukkan pemangsa mempunyai pilihan dan niat tersendiri untuk melakukan jenayah. Mangsa pemangsa mempunyai target yang tersendiri dan berpotensi di matanya. Mangsa tidak menjadi tidak berdaya dengan sengaja namun di atas faktor umur yang muda, kekurangan kekuatan fizikal, ketakutan, kekurangan didikan dan pengetahuan mengenai, tidak bernasib baik kerana berkongsi lokasi bersama pemangsa dan penjaga yang tidak menjalankan tanggungjawab dengan baik. Jadi, mangsa tidak seharusnya dipersalahkan dan dikatakan mencetus serangan seksual $\mathrm{k}$ atas diri mereka. 


\section{Rujukan}

Adams-Curtis, L. E., \& Forbes, G. B. (2004). College Women's Experiences Of Sexual Coercion. Trauma, Violence, \& Abuse, 5(2), 91-122.

Audit Office of NSW. (2011). New South Wales Auditor-General's report: Performance audit: Responding to domestic and family violence: Department of Family and Community Services, department of attorney-general and Justice, Ministry of Health, Nsw police force.

Cohen, L., \& Felson, M. (1979). Social Change and Crime Rate Trends: A Routine Activity Approach. American Sociological Review, 44(4), 588-608. Retrieved September 21, 2020, from http://www.jstor.org/stable/2094589

Degarmo, M. (2011). Understanding The Comparisons Of Routine Activities And Contagious Distributions Of Victimization: Forming A Mixed Model Of Confluence And Transmission", International Journal Of Criminology And Sociological Theory, 4(1), 584-603

Uğur Argun, Murat (2016). Dağlar Examination of Routine Activities Theory by The Property Crime. International Journal of Human Sciences. 10.14687/ijhs.v13i1.3665

Holtfreter, K., Reisig, M. D., \& Pratt, T. C. (2008). Low Self-Control, Routine Activities, And Fraud Victimization. Criminology, 46(1), 189-220.

Kennedy, L.W., \& Forde, D. R. (1990). Routine Acitivites and Crime: An Analysis of Victimiation in Canada. Criminology, 8(1), 137-15

M J Hindelang; M R Gottfredson; J Garofalo. (1978). Victims of Personal Crime - An Empirical Foundation for a Theory of Personal Victimization. Ballinger Publishing CoNSW Attorney General's Department. 2011. Sydney NSW

Miró, F. (2014). Routine Activity Theory. The Encyclopedia of Theoretical Criminology, 1-7

Moriarty, L.J., Williams, J.E. (1996). Examining The Relationship between Routine Activities Theory and Social Disorganization: An analysis of Property Crime Victimization. AJCJ, 21, 43-59.

Sampson, R.J. \& Wooldredge, J.D. (1987). Linking The Micro- and Macro-level Dimensions of Lifestyle-Routine Activity and Opportunity Models of Predatory Victimization. J Quant Criminol 3, 371-393

T. C., \& Turanovic, J. J. (2015). Lifestyle and Routine Activity Theories Revisited: The Importance of "Risk" to the Study of Victimization. Victims \& Offenders, 11(3), 335-354

Uğur Argun \& Murat Dağlar. (2016). Examination of Routine Activities Theory by the property. Crime. International Journal of Human Sciences.

Wikström \& Per-Olof. 2009. Crime Propensity, Criminogenic Exposure and Crime Involvement in Early to Mid Adolescence. Monatsschrift für Kriminologie und Strafrechtreform

Zerubavel, N., \& Messman-Moore, T. L. (2013). Sexual victimization, Fear of Sexual Powerlessness, and Cognitive Emotion Dysregulation as Barriers to Sexual Assertiveness in College Women. Violence Against Women, 19(12), 1518-1537 